\title{
Decolorization and Detoxification of Synthetic Dyes by Mexican Strains of Trametes sp.
}

\author{
Laura N. Levin ${ }^{1}$, Carlos E. Hernández-Luna ${ }^{2}$, Guillermo Niño-Medina ${ }^{3}{ }^{\mathbb{D}}$, \\ Juan Pablo García-Rodríguez ${ }^{3}$, Iosvany López-Sadin ${ }^{3,4}$, Gerardo Méndez-Zamora ${ }^{3}$ (i) \\ and Guadalupe Gutiérrez-Soto ${ }^{3, *(D)}$ \\ 1 Laboratorio de Micología Experimental, Departamento de Biodiversidad y Biología Experimental, Facultad \\ de Ciencias Exactas y Naturales, Universidad de Buenos Aires, INMIBO-CONICET, Buenos Aires 1428 \\ CABA, Argentina; lale@bg.fcen.uba.ar \\ 2 Laboratorio de Enzimología, Facultad de Ciencias Biológicas, Universidad Autónoma de Nuevo León, Pedro \\ de Alba S/N., Ciudad Universitaria, San Nicolás de los Garza, Nuevo León C.P. 66455, Mexico; \\ carlosehlmx@yahoo.com \\ 3 Universidad Autónoma de Nuevo León, Facultad de Agronomía, Francisco Villa S/N., Col. Ex Hacienda El \\ Canadá, General Escobedo, Nuevo León C.P. 66050, Mexico; nino.medina.g@gmail.com (G.N.-M.); \\ jpablo.garciar14@gmail.com (J.P.G.-R.); iosvanyls@gmail.com (I.L.-S.); mezage@hotmail.com (G.M.-Z.) \\ 4 Departamento de Mecánica Aplicada, Facultad de Ciencias Técnicas, Universidad de Ciego de Ávila, \\ Carretera a Morón, Km 9 1/2, Ciego de Ávila C.P. 69450, Cuba \\ * Correspondence: ggutierrez0402@gmail.com; Tel.: +52-8183-2940-00 (ext. 3515)
}

Received: 2 October 2019; Accepted: 26 October 2019; Published: 20 November 2019

\begin{abstract}
Laccases have attracted a great deal of interest because of their remarkable ability for the degradation of synthetic dyes present in wastewaters. New laccase producing sources with robust operational and functional properties are being continuously explored. In this work, the potential for the decolorization and detoxification of synthetic dyes was evaluated in two Mexican strains of the genus Trametes. The decolorization capacity of Trametes maxima LE130 and Trametes sp. LA1 was tested in solid and liquid media. The phytotoxicity of the degradation products was determined using Raphanus sativus and Pisum sativum seeds. In solid media, both strains showed a higher decolorization capacity ( $p \leq 0.05$ ) than Phanerochaete chrysosporium ATCC 24725, which is known to be very efficient in lignin and dye-degradation. They produced laccase as the main ligninolytic enzyme; T. maxima LE130 secreted a single isoform of $43.9 \mathrm{kDa}$, while Trametes sp. LA1 produced three isoforms of $67.3,58.6$ and $52.7 \mathrm{kDa}$, respectively. Trametes sp. LA1 culture fluids were capable of decolorizing and detoxifying chemically diverse dyes (anthraquinonic dye Remazol Brilliant Blue R, azoic Reactive Black 5 and triphenylmethane Crystal Violet) without the addition of redox mediators. Therefore, this could be considered as a new laccase source which could be potentially competitive in the bioremediation of dye-containing wastewaters.
\end{abstract}

Keywords: detoxification; dye decolorization; isoforms; laccase; waste water

\section{Introduction}

Synthetic dyes are used globally in numerous industries, such as in the textile, paper printing, food, pharmaceutical, leather and cosmetics industries. They produce large amounts of colored liquid wastes containing toxic chemicals, some of which are non-biodegradable and carcinogenic and pose a major threat to the environment and human health [1]. Due to their synthetic origin and complex aromatic molecular structures, their treatment is often expensive and inefficient. To date, there is no highly effective technique which is capable of the complete removal of both the color and the toxic properties of the dyes released into the environment [1]. Microbial dye detoxification is promising because of its 
low-cost and relative ease of technological development. Nevertheless, azo compounds are susceptible of forming more hazardous products such as aromatic amines after being reduced or decolorized by bacterial azoreductases [2]. The role of fungi and their enzymes and their potential use in the degradation and detoxification of dyes has been well reported and recognized [3]. The most widely used of these are white rot fungi. Their nonspecific lignin-degrading systems-mainly composed of laccase, and peroxidases such as $\mathrm{Mn}$-peroxidase $(\mathrm{MnP})$ and lignin-peroxidase (LiP) — degrade dyes by oxidation $[4,5]$. The relative contribution of different enzymes in fungal cultures to decolorization is not yet completely understood [6]. As the enzymatic system secreted by basidiomycetes depends even on the strain and culture conditions, more white-rot fungi need to be screened for their ability to degrade dyes [7]. Laccases (benzenediol: oxygen oxidoreductases, EC 1.10.3.2) are considered ideal "green catalysts" as they do not require hydrogen peroxide for their oxidation reaction and use molecular oxygen as an electron acceptor, generating water. Among them, high-redox potential laccases, which may oxidize a wider range of substrates including those reported for peroxidases, are very attractive for biotechnological purposes [8]. A lower redox potential $\left(\mathrm{E}^{\circ}\right)$ of the substrate and/or a higher $\mathrm{E}^{\circ}$ of laccase normally results in a higher rate of substrate oxidation, and a linear correlation between the percentage of decolorization of each dye and the respective redox potential was found [9]. Recently, there has been growing interest in studying new fungal laccase sources, with the expectation of finding enzymes with novel properties or which are very robust for application in dye decolorization [10-12]. One of the limitations of the large-scale application of the enzyme is the lack of a capacity to produce large volumes of highly active enzyme. These problems can be solved with the use of recombinant organisms or with screening for natural hyper secretory strains [13]. The information available in the literature regarding the detoxification of textile effluents with laccases is scarce, and no strict correlation has been found between decolorization and detoxification [10,14-16]. The identification of the metabolites produced during the decolorization and/or biodegradation of a certain dye, as well as the evaluation of their toxicity, is an essential step for the eventual application of a laccase, assuring the safety of the treated effluents [3].

Mexico is considered to be one of the most mega-diverse countries of the world; it hosts more than $10 \%$ of the world's biological diversity [17]. In Mexico, it is estimated that 200,000 fungal species occur, and only about $5 \%$ have been studied [18], indicating a lack of knowledge about this group of microorganisms and highlighting the necessity of performing further investigations. They represent an important resource from the technological point of view because they can be used in a broad variety of industrial processes. A screening for thermo-tolerant ligninolytic fungi with laccase, lipase and protease activity, isolated in the large area of forests known as the Huasteca Hidalguense in the state of Hidalgo (Mexico), was conducted by Cruz-Ramirez et al. [19]. Gutiérrez-Soto et al. [20] explored the lignocellulolytic potential of 74 strains isolated in northeastern Mexico. Several species of the genus Trametes (Aphyllophorales, Polyporaceae) are considered as good laccase producers (i.e., Trametes versicolor, Trametes hirsuta and Trametes trogii) [21]. In this work, the potential for the decolorization and detoxification of synthetic dyes was evaluated in two Mexican strains of the genus Trametes.

\section{Materials and Methods}

\subsection{Fungal Strains and Culture Conditions}

Trametes maxima LE130 and Trametes sp. LA1 were provided by the culture collection of the Laboratory of Enzymology, Biology Department from the UANL (Nuevo León Autonomous University). Phanerochaete chrysosporium ATCC 24,725 was used for comparison. All strains were conserved in YMGA (glucose $4 \mathrm{~g} \mathrm{~L}^{-1}$, malt extract $10 \mathrm{~g} \mathrm{~L}^{-1}$, yeast extract $4 \mathrm{~g} \mathrm{~L}^{-1}$ and agar $15 \mathrm{~g} \mathrm{~L}^{-1}$ ) slants at $4{ }^{\circ} \mathrm{C}$ with periodic subcultures every three months. The growth media consisted of liquid Bran Flakes medium (BF) (2\% (w/v) Kellogg's $\mu$ Bran Flakes) in $60 \mathrm{mM}$ potassium phosphate buffer $\mathrm{pH} 6.0$ [22] and the rich medium for Basidiomycota (BRM) reported by Bezalel et al. [23]. Additionally, the effects of $\mathrm{MnSO}_{4}(0.1 \mathrm{mM}), \mathrm{FeSO}_{4}(0.1 \mathrm{mM}), \mathrm{CuSO}_{4}(0.35 \mathrm{mM})$ and ethanol $(3 \%)$ were evaluated as inducers of 
$\mathrm{MnP}, \mathrm{LiP}$ and laccase activity, respectively [7,24,25]. Erlenmeyer flasks $(500 \mathrm{~mL})$ containing $200 \mathrm{~mL}$ of growth media were inoculated with $10 \mathrm{~mm}$ diameter plugs cut out from the margin of a 7-day-old colony growing on PDA media and incubated statically at $28{ }^{\circ} \mathrm{C}$ for 20 days. The final $\mathrm{pH}$ of all media was adjusted to 6.0. Cultures were harvested at proper intervals (every two days), and $2 \mathrm{~mL}$ aliquots of the supernatant were collected aseptically and used as enzyme sources.

\subsection{Enzymatic Assays}

Laccase activity was determined by following the oxidation of 2,6 dimethoxyphenol (DMP) at $468 \mathrm{~nm}\left(\varepsilon_{468}(\right.$ molar extinction coefficient $\left.)=49,600 \mathrm{M}^{-1} \mathrm{~cm}^{-1}\right)$ [26]. $\mathrm{MnP}$ was measured at $270 \mathrm{~nm}$ $\left(\varepsilon_{270}=11,590 \mathrm{M}^{-1} \mathrm{~cm}^{-1}\right)$ by the formation of $\mathrm{Mn}^{3+}$ malonate complexes according to Wariishi et al. [27]. $\mathrm{LiP}$ was measured with veratryl alcohol by following the formation of veratraldehyde at $310 \mathrm{~nm}$ $\left(\varepsilon_{310}=9300 \mathrm{M}^{-1} \mathrm{~cm}^{-1}\right)$ [28]. Enzymatic activities were expressed in units (U) defined as the amount of enzyme required to produce $1 \mu \mathrm{mol}$ of product. Enzymatic reactions were carried out at $25^{\circ} \mathrm{C}$ and $\mathrm{pH}$ 3.5 and evaluated in a UV-Vis 1800 spectrophotometer (Shimadzu)).

\subsection{Solid-Plate Dye Decolorization}

All the strains were inoculated on agar plates in BF medium supplemented with $200 \mathrm{ppm}$ of each of the dyes evaluated (depicted in Table 1). Inoculum consisted of a $50 \mathrm{~mm}$ agar disc of a 5 days old culture grown on YMGA. Non-inoculated plates served as controls for abiotic decolorization. Each fungus was tested in three independent experiments on all plates. The plates were incubated at $28{ }^{\circ} \mathrm{C}$ for 30 days. Growth was followed by measuring the radial extension of the mycelium. A decolorized zone appeared when the fungus degraded the dye. Daily measurements of the colonies and the decolorized zones (if any) were taken for each strain. Decolorization index (DI) was calculated as the ratio between the decolorized zone and colony diameter.

Table 1. Dyes used in the experiment, their commercial and color index (CI) number, acronym, class and chemical structure.

\begin{tabular}{|c|c|c|c|c|}
\hline $\begin{array}{l}\text { Commercial } \\
\text { Name }\end{array}$ & CI Number & Acronym & Dye Class & $\begin{array}{l}\text { Chemical } \\
\text { Structure }\end{array}$ \\
\hline $\begin{array}{c}\text { Basic Violet } 3 \\
\text { (Crystal Violet) }\end{array}$ & 42555 & $\mathrm{CV}$ & $\begin{array}{l}\text { Triphenyl } \\
\text { methane }\end{array}$ & \\
\hline $\begin{array}{c}\text { Direct Black } 22 \\
\text { (Direct Black CA) }\end{array}$ & 35435 & DB22 & Azo & \\
\hline $\begin{array}{l}\text { Acid Orange } 7 \\
\text { (Orange II) }\end{array}$ & 15510 & OII & Azo & \\
\hline
\end{tabular}


Table 1. Cont.

\begin{tabular}{|c|c|c|c|c|}
\hline $\begin{array}{l}\text { Commercial } \\
\text { Name }\end{array}$ & CI Number & Acronym & Dye Class & $\begin{array}{l}\text { Chemical } \\
\text { Structure }\end{array}$ \\
\hline $\begin{array}{c}\text { Reactive Black } 5 \\
\text { (Remazol Black B) }\end{array}$ & 20505 & RB5 & Azo & \\
\hline $\begin{array}{l}\text { Reactive Blue } 19 \\
\text { (Remazol Brilliant Blue } \\
\text { R) }\end{array}$ & 61200 & RBBR & Anthraquinone & \\
\hline (Methylene Azure B) & 52010 & $\mathrm{AB}$ & Heterocyclic & \\
\hline Poly R-478 & & PR & Polymeric & \\
\hline
\end{tabular}

\subsection{Decolorization in Liquid Medium}

Decolorization was investigated in a batch system with BRM medium by adding 200 ppm of either the anthraquinonic dye Remazol Brilliant Blue R (RBBR), the azoic Reactive Black 5 (RB5) or the triphenylmethane type Crystal Violet (CV) to 18 day cultures of the evaluated fungi, incubated at $28^{\circ} \mathrm{C}$ and $200 \mathrm{rpm}$. The absorption spectra were measured in the range $200-800 \mathrm{~nm}$ at $0,2,4,6,8$ and $24 \mathrm{~h}$. Color reduction was followed spectrophotometrically, and decolorizing activity was calculated from the decrease in absorption of the peak maximum for each dye (592 for RBBR, 597 for RB5, and 588 for CV). Afterwards, the supernatants were collected by filtration and employed for toxicity assays. The dye adsorbed to the mycelium was desorbed with ethanol: water (1:1), and its concentration was calculated in the same way as the percentage of decolorization. For this, the cultures were filtered on Whatman No. 1 paper, and the recovered mycelium was washed with the mentioned dilution of ethanol.

\subsection{Polyacrylamide Gel Electrophoresis (PAGE) and Activity Staining of Gels}

Ligninolytic enzymes and their involvement in dye decolorization were assessed by Sodium Dodecyl Suphate-Polyacrylamide Gel Electrophoresis (SDS-PAGE) of the crude extracts [29]. Separation was carried out on vertical polyacrylamide slab gels. Electrophoresis was performed on $12 \%$ polyacrylamide gel under denaturing conditions (SDS-PAGE). The buffer solution for the separating gel was $1.5 \mathrm{mM}$ ( $\mathrm{pH} 8.8$ ). Twenty-five $\mu \mathrm{g}$ of protein culture filtrates from different incubation days were loaded onto the gel and electrophoresed with Tris/Glycine buffer ( $\mathrm{pH} 8.3$ ) at $100 \mathrm{~V}$. Proteins separated in the gel were stained with Coomassie Brilliant Blue R, and their molecular mass was estimated with Precision Plus Protein ${ }^{\mathrm{TM}}$ Kaleidoscope ${ }^{\mathrm{TM}}$ Prestained Protein Standards (BioRad, Louisville, Kentucky, USA). The zymograms were revealed with DMP as cofactors for $\mathrm{LiP}\left(\mathrm{H}_{2} \mathrm{O}_{2}\right)$ and $\mathrm{MnP}\left(\mathrm{H}_{2} \mathrm{O}_{2}\right.$ and $\left.\mathrm{Mn}^{+2}\right)$ 
activities, respectively. Afterwards, the gel was fixed for $15 \mathrm{~min}$ in $10(\mathrm{v} / \mathrm{v})$ acetic acid and $40(\mathrm{v} / \mathrm{v})$ methanol, and then soaked in $200 \mathrm{mM}$ acetate buffer ( $\mathrm{pH}$ 3.5) containing $2 \mathrm{mM} / \mathrm{mL}$ of DMP. Protein bands exhibiting laccase activity were stained orange with DMP within $10 \mathrm{~min}$. The anthraquinonic dyes RBBR and Acid Green 27 (AG27) were utilized for the inverse zymograms. The gels were immersed in $200 \mathrm{mM}$ sodium acetate (pH 3.5), with $1 \mathrm{~mL} 2 \%$ AG27 or RBBR. They were shaken gently for $1 \mathrm{~h}$, until evidence of clearing bands appeared.

\subsection{Phytotoxicity Bioassay}

The phytotoxicity of the dyes and their derivates were determined using Raphanus sativus var. Champion and Pisum sativum var. Lincoln seeds (IMAISA S.A., Nuevo León, México). They were incubated for 5 days at $25^{\circ} \mathrm{C}$ with either (a) control (water); (b) a fresh solution of the dye (200 ppm) or (c) the dye solution treated for $24 \mathrm{~h}$ with each fungus. Ten seeds were evaluated in each Petri dish. Every treatment was carried out in triplicate.

The germination percentage was calculated considering the visible appearance of the radicle [30]. The damage in the radicle $(R d)$ was calculated according to Equation (1):

$$
(1): R d=\frac{\text { Radicle length control }- \text { Radicle length test }}{\text { Radicle length control }} * 100
$$

Dye detoxification was estimated using the formula of Sobrero and Ronco [31]:

$$
\text { Detoxification }=\frac{(\% T)(100)}{(\% C)}
$$

where $\% \mathrm{~T}$ and $\% \mathrm{C}$ are respectively, the percentages of inhibition on germination or the damage of the radicle in the treated samples and in the control.

Lethal or sub-lethal damage was determined in the seeds that did not germinate. These seeds were subjected to a test of viability [32]. Seeds that did not germinate were placed in Petri dishes with Whatman paper, and then saturated with $4 \mathrm{~mL}^{-1}$ distilled water. The plates were incubated at $25 \pm 2{ }^{\circ} \mathrm{C}$, for a period of 4 and 5 days. The amount of seeds that germinated was documented, thus confirming the viability and determining the type of effect the treatments and controls had on the seeds. In those that did not germinate when exposed to the treatments and those in which, when subjected to the simple germination test, the protrusion of the seed by the radicle was observed, sub-lethal damage was considered to have occurred.

\subsection{Statistical Analysis}

Data were subjected to ANOVA using the SPSS Statistics 10.0 (SPSS, Chicago, IL, USA) software program. Data of the analytical determinations are the average of the results of three replications. The significant differences between treatments were compared by Tukey's test at a $5 \%$ level of probability.

\section{Results and Discussion}

\subsection{Solid-Plate Dye Decolorization}

The broad-spectrum decolorization efficiency of the isolates was evaluated using chemically different dyes representative of the most used dyes (Table 1). Poly R-478, characterized by a chemical complexity similar to lignin compounds, allows the assessment of the fungal capability of degrading lignin and aromatic molecules [33], while Azure B was employed to detect LiP activity [34]. The results obtained are depicted in Table 2. Trametes sp. LA1 displayed the best results in Poly R-478 while T. maxima LE130 performed best in Azure B (respectively, DI $=0.35$ and 0.64 at day 5 of cultivation). Under the conditions assayed, P. chrysosporium ATCC 24,725 was reported as an efficient LiP and dye decolorizing strain [35], which only partially decolorized Azure B and Acid Orange (OII) plates after 
15 days (Table 2) and Poly R-478 after 30 days (data not shown). No statistically significant differences were registered among Trametes sp. LA1 DI of Direct Black (DB), OII, RB5 and RBBR. The best DI values were attained with CV. T. maxima LE130 rendered the highest DI for all the dyes evaluated. The different DI values reflect the different capacities of the fungal cultures to remove dyes with diverse chemical structures. Small structural differences between the dyes could significantly affect their decolorization. This might be due to differences in electron distribution, charge density or steric factors [36].

Table 2. Solid-plate dye decolorization in Bran Flakes (BF) medium supplemented with 200 ppm of each of the dyes evaluated.

\begin{tabular}{ccccccccc}
\hline \multirow{2}{*}{$\begin{array}{c}\text { Strain/ } \\
\text { Days }\end{array}$} & PR & AB & CV & DB22 & OII & RB5 & RBBR & \\
\cline { 2 - 8 } & & & & & & & & $0.016 />0.05$ \\
A & & 0.000 & 0.000 & 0.000 & 0.000 & 0.000 & 0.000 & \\
5 & 0.000 & 0. Value \\
7 & 0.000 & 0.000 & 0.000 & 0.000 & 0.000 & 0.000 & 0.000 & \\
15 & 0.000 & 0.063 & 0.000 & 0.000 & 0.042 & 0.000 & 0.000 & \\
B & & & & & & & & $0.121 / 0.0001$ \\
5 & $0.00 \mathrm{~b}$ & $0.639 \mathrm{a}$ & $0.000 \mathrm{~b}$ & $0.000 \mathrm{~b}$ & $0.690 \mathrm{a}$ & $0.866 \mathrm{a}$ & $0.778 \mathrm{a}$ & \\
7 & $0.000 \mathrm{~b}$ & $0.847 \mathrm{a}$ & $0.000 \mathrm{~b}$ & $0.000 \mathrm{~b}$ & $0.822 \mathrm{a}$ & $0.908 \mathrm{a}$ & $0.932 \mathrm{a}$ & \\
15 & $1.000 \mathrm{a}$ & $1.000 \mathrm{a}$ & $2.543 \mathrm{a}$ & $1.000 \mathrm{a}$ & $1.000 \mathrm{a}$ & $1.000 \mathrm{a}$ & $1.000 \mathrm{a}$ & \\
$\mathbf{C}$ & & & & & & & & $0.278 />0.05$ \\
5 & 0.350 & 0.316 & 0.000 & 0.282 & 0.363 & 0.364 & 0.358 & \\
7 & 0.369 & 0.361 & 1.333 & 0.369 & 0.358 & 0.381 & 0.393 & \\
15 & 0.413 & 0.413 & 1.059 & 0.413 & 0.413 & 0.413 & 0.413 & \\
\hline
\end{tabular}

(A) P. chrysosporium ATCC 24725, (B) T. maxima LE130, (C) Trametes sp. LA1. SE: standard error of the mean. ${ }^{a-b}$ Means in rows with different superscripts indicate significant differences between treatments $(p \leq 0.05)$.

\subsection{Production of Ligninolytic Enzymes in Liquid Media}

Among the ligninolytic enzymes evaluated, only laccase activity was detected in the culture fluids of both strains in all the media assayed. The highest titers were quantified in medium BRM supplemented with $0.1 \mathrm{mM} \mathrm{MnSO}_{4}, 0.1 \mathrm{mM} \mathrm{FeSO}_{4}, 0.35 \mathrm{mM} \mathrm{CuSO}_{4}$ and $3 \%$ ethanol (Figure 1). Trametes sp LA1 produced $80 \mathrm{U} \mathrm{L}^{-1}$ at day 18, while T. maxima $\mathrm{LE} 130$ produced $35 \mathrm{U} \mathrm{L}^{-1}$ at day 12.
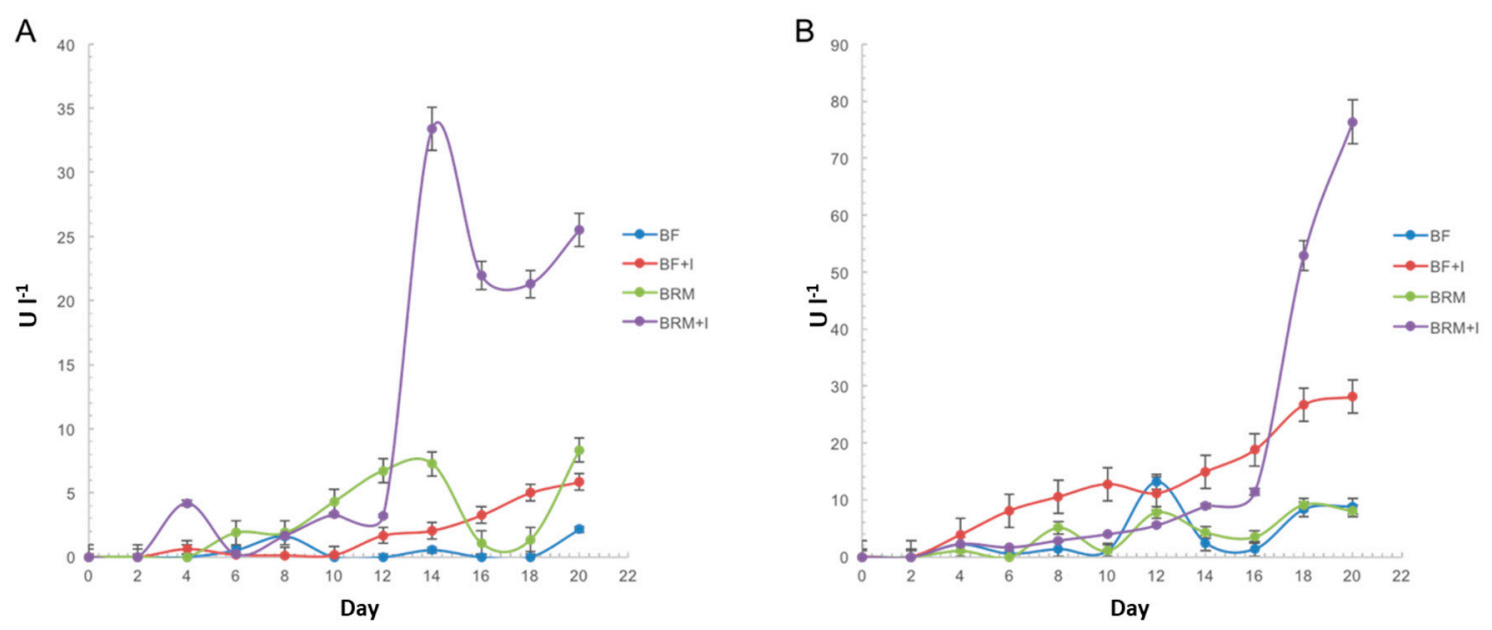

Figure 1. Time course of laccase production in BF or rich medium for Basidiomycota (BRM) media, alternatively supplemented with $0.1 \mathrm{mM} \mathrm{MnSO}_{4}, 0.1 \mathrm{mM} \mathrm{FeSO}_{4}, 0.35 \mathrm{mM} \mathrm{CuSO}_{4}$ and $3 \%$ ethanol $(\mathrm{BF}+\mathrm{I}, \mathrm{BRF}+\mathrm{I})$ by (A) T. maxima LE130 and (B) Trametes sp. LA1. The values are the mean of three replications $\pm \mathrm{SE}$. 
The absence of noticeable levels of $\mathrm{LiP}$ and MnP was confirmed by SDS-PAGE gels, revealed by 2,6-DMP and the cofactors required for each enzyme $\left(\mathrm{H}_{2} \mathrm{O}_{2}\right.$ and $\mathrm{H}_{2} \mathrm{O}_{2}+\mathrm{Mn}^{+2}$, respectively). Laccase was the only activity detected in these gels (Figure 2). In Trametes species, laccases are the major enzymes, but peroxidases are also secreted during dye decolorization [7]. Nevertheless, under the conditions assayed in this work, peroxidase activity was not detected. In both strains assayed, the laccase isoenzymatic profile did not vary between days 14 and 20. T. maxima LE130 produced a single laccase isoform $\left(\mathrm{Lac}_{T m}\right)$, with a molecular weight of $43.9 \mathrm{kDa}$. Trametes sp LA1 produced three isoforms $\left(\mathrm{Lac}_{T s p} \mathrm{I}_{\text {, }} \mathrm{Lac}_{T s p}\right.$ II, $\left.\mathrm{Lac}_{T s p} \mathrm{III}\right)$, with molecular weights of, respectively, 67.3, 58.6 and $52.7 \mathrm{kDa}$. The molecular masses reported in this study are in the range observed for laccases isolated from other white-rot fungi; usually, molecular masses of fungal laccases range from 30 to $300 \mathrm{kDa}$ [37]. Laccase decolorizing activity was assayed by inverse zymograms, as revealed with the dyes AG27 and RBBR (Figure 2). In T. maxima LE130 zymograms stained with AG27 (Figure 2A), a precipitate was observed coincident with the laccase activity band, possibly resulting from dye polymerization. The capacity of phenoloxidases to polymerize phenols is widely documented (for both free and immobilized laccase) [38]. T. maxima LE130 laccase activity did not show potential for decolorizing RBBR. RBBR decolorization by T. maxima LE130 laccase might require the presence of redox mediators. The potential of synthetic dye decolorization by purified laccases has been described in several species; however, most dyes are only transformed in the presence of redox mediators [39]. Natural laccase mediators [40] may be present in the extracellular fluids of the fungus, which proved capable of decolorizing $55 \%$ of this dye after $24 \mathrm{~h}$ (Table 3). All laccase isoforms from Trametes sp. LA1 showed decolorizing

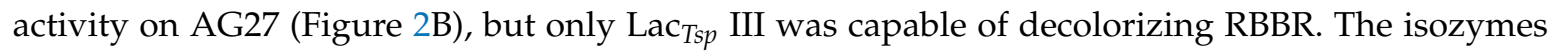
may have different substrate affinity, which may affect their decolorization potential [41]. Finding laccase as the principal activity responsible for decolorization is consistent with previous reports with Trametes hispida [42] and T. hirsuta [26]. However, further studies with pure enzymes are necessary to corroborate this conclusively.
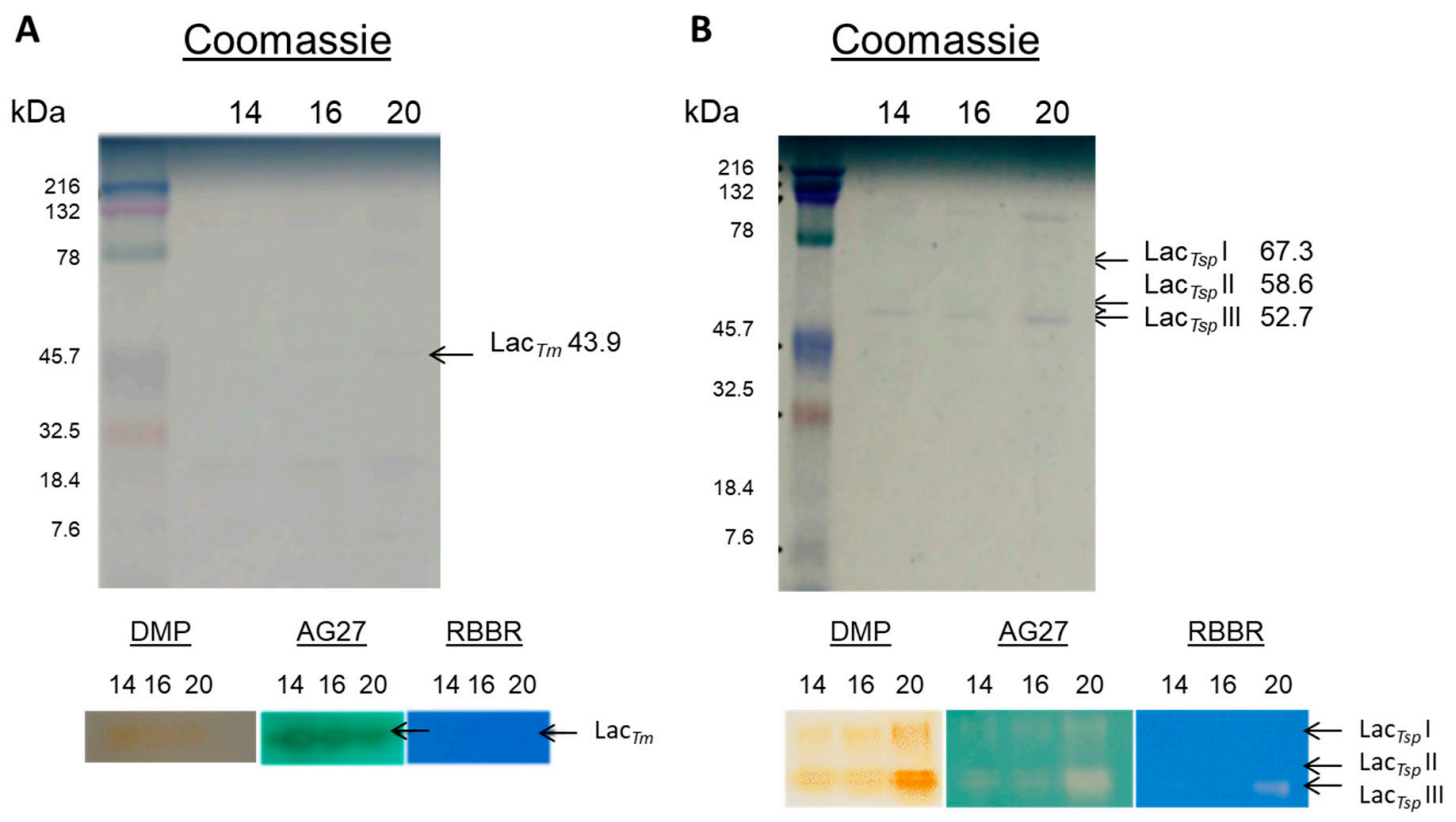

Figure 2. SDS-PAGE and laccase zymograms. (A) T. maxima LE130 SDS-PAGE and zymograms with 2,6 dimethoxyphenol (DMP), Acid Green 27 (AG27) and RBBR. (B) Trametes sp. LA1 SDS-PAGE and zymograms with DMP, AG27 and RBBR. Culture supernatants were obtained after 14, 16 and 18 days of incubation. 
Table 3. Decolorization of dyes by liquid cultures of T. maxima LE130 and Trametes sp. LA1 grown in $\mathrm{BRM}$ medium at $28^{\circ} \mathrm{C}$. Decolorization was investigated by adding $200 \mathrm{ppm}$ of either the anthraquinonic dye RBBR, the azoic RB5 or the triphenylmethane CV to 18 day cultures of the evaluated fungi.

\begin{tabular}{|c|c|c|c|c|c|}
\hline \multicolumn{6}{|c|}{ T. Maxima LE130 } \\
\hline & \multicolumn{3}{|c|}{ Decolorization (\%) } & \multirow[b]{2}{*}{ Parameter } & \multirow{2}{*}{$p$-value } \\
\hline lime (h) & $\mathrm{CV}$ & RB5 & RBBR & & \\
\hline 0 & 0.00 & 0.00 & 0.00 & Model & 0.0312 \\
\hline 2 & 12.95 & 43.92 & 45.23 & Dye (D) & 0.0003 \\
\hline 4 & 25.40 & 51.50 & 46.17 & Time $(t)$ & 0.1875 \\
\hline 6 & 27.58 & 51.66 & 46.54 & $D * t$ & 0.9884 \\
\hline 8 & 27.47 & 55.19 & 47.74 & & \\
\hline 24 & 41.05 & 61.01 & 54.94 & & \\
\hline$S E(t)$ & 7.84 & 7.84 & 8.49 & & \\
\hline$C($ mean $\pm S D)$ & $26.89 \pm 3.5^{b}$ & $52.66 \pm 3.5^{\mathrm{a}}$ & $48.12 \pm 3.84^{\mathrm{a}}$ & & \\
\hline \multicolumn{6}{|c|}{ Trametes sp. LA1 } \\
\hline 0 & 0.00 & 0.00 & 0.00 & Model & 0.0028 \\
\hline 2 & 63.40 & 44.45 & 39.50 & Dye (D) & $\leq 0.0001$ \\
\hline 4 & 70.80 & 50.00 & 44.90 & Time $(\mathrm{t})$ & 0.3103 \\
\hline 6 & 74.45 & 51.00 & 43.70 & $D * t$ & 0.9946 \\
\hline 8 & 76.60 & 46.90 & 42.90 & & \\
\hline 24 & 79.70 & 54.80 & 49.60 & & \\
\hline $\mathrm{SE}(\mathrm{t})$ & 6.17 & 6.17 & 8.72 & & \\
\hline $\mathrm{C}($ mean $\pm \mathrm{SD})$ & $72.99 \pm 2.76^{\mathrm{a}}$ & $49.43 \pm 2.76^{b}$ & $44.12 \pm 3.02^{b}$ & & \\
\hline
\end{tabular}

C: mean and standard deviation (SD) by columns. ${ }^{\mathrm{a}-\mathrm{b}}$ Means in rows with different superscripts indicate significant differences between treatments $(p \leq 0.05)$. SE: standard error of the mean.

\subsection{Decolorization of Dyes by Liquid Cultures}

Both strains assayed showed significant differences $(p \leq 0.05)$ in their ability to decolorize dyes with diverse chemical structures. After $24 \mathrm{~h}$, the best results were obtained by T. maxima LE130 with the azo dye RB5 (61\% decolorization), while the triarylmethane $\mathrm{CV}$ was more resistant to biodegradation (Table 3). However, Trametes sp. LA1 could decolorize CV more effectively $(p \leq 0.05)$ (approximately $80 \%$ ). The role of adsorption on the fungal mycelium in dye decolorization was minimal. The dyes were rapidly removed from the medium because of physical adsorption, but they were later eliminated from both the solution and the surface of the mats because of the enzymatic degradation. At the end of the experiment, sorption accounted for less than 5\%. Aretxaga et al. [43] as well as Levin et al. [44] obtained similar results when they evaluated dye decolorization by T. versicolor. Sorption was responsible for less than $3 \%$ of azo and triphenylmethane dye removal by ligninolytic (dye-decolorizing) cultures of Pycnoporus sanguineus [45].

\subsection{Phytotoxicity Assays}

The phytotoxicity of CV, RBBR and RB5 before and after treatment with T.maxima LE130 and Trametes sp. LA1 cultures was assessed by the analysis of their effects on seed germination, radicle length and damage, using R. sativus (Table 4) and P. sativum seeds (Table 5). CV was the only dye which altered $R$. sativus germination. However, all the dyes assayed caused severe damages to the radicle (approximately 90\%). Treated dyes with T. maxima LE130 were more toxic than the untreated ones (showing significant differences not only in seed germination percentages but also in radicle length). Treatment with Trametes sp. LA1 reduced the toxicity of the triphenylmethane dye CV; treated dyes did not affect the germination of these seeds, but also markedly diminished radicle damage (55\% decrease) and growth inhibition in comparison with the untreated dyes. Laccase activity might be involved in decolorization and detoxification processes, considering that Trametes sp. LA1 laccase titers in cultures applied in decolorization $\left(80 \mathrm{U} \mathrm{L}^{-1}\right)$ were more than twice those registered in T. maxima LE130 culture fluids, and concomitantly, Trametes sp. LA1 was capable of decolorizing approximately $80 \%$ of $200 \mathrm{ppm}$ 
CV, while T. maxima LE130 cultures only decolorized $40 \%$ of this dye (Figure 1, Table 3). Germination percentages did not vary significantly between RB5-untreated and Trametes sp. LA1-treated samples, but radicle damage decreased ( $8 \%$ ) and length increased with Trametes sp. LA1 treatment. On the contrary, Trametes sp. LA1-treated RBBR slightly inhibited growth germination and decreased root elongation. The effects varied when assaying P. sativum seeds, but CV was the only dye that affected both radicle length and damage. Treated dyes with T. maxima LE130 were more toxic than the untreated ones (the root lengths of selected plants decreased with all the treated dyes and germination diminished when applying T. maxima LE130-treated CV). However, CV metabolites present after with Trametes sp. LA1-treatment did not affect seed germination, although the negative effects of $\mathrm{CV}$ on root elongation and damage persisted. P. sativum root elongation was neither affected by RBBR and RB5 nor by the metabolites which resulted after treatment. Radicle damage was also not observed. The abiotic controls as well as the three dyes treated with T. maxima LE130 and Trametes sp. LA1-treated RB5 and RBBR only produced sub-lethal effects on both seeds, as they conserved their germination capacity.

Table 4. Phytotoxicity of the dyes on $R$. sativus seeds before and after $24 \mathrm{~h}$ treatment with $T$. maxima LE130 and Trametes sp. LA1 cultures.

\begin{tabular}{|c|c|c|c|c|c|}
\hline Dye $^{\Psi}$ & Control * & Untreated Dye & LE130-Treated Dye & LA1-Treated Dye & $\mathrm{SE} / p$-Value \\
\hline \multicolumn{5}{|c|}{ Germination inhibition (\%) } & $5.53 / \leq 0.0001$ \\
\hline $\mathrm{CV}$ & $3.33^{c ; A}$ & $56.67^{\mathrm{b} ; \mathrm{A}}$ & $83.33^{\text {a; }} \mathrm{A}$ & 0.00 c; B & \\
\hline RB5 & $3.33^{\mathrm{b} ; \mathrm{A}}$ & $16.67^{b ; B}$ & 40.00 a; B & $16.67^{\mathrm{b} ; \mathrm{A}}$ & \\
\hline RBBR & $3.33^{\mathrm{b} ; \mathrm{A}}$ & $6.67^{b ;}$ B & $93.33^{\text {a; }} \mathrm{A}$ & $20.00^{\mathrm{b} ; \mathrm{A}}$ & \\
\hline \multicolumn{5}{|c|}{ Radicle length (cm) } & $0.08 / \leq 0.0001$ \\
\hline $\mathrm{CV}$ & $5.87^{\mathrm{a} ; \mathrm{A}}$ & $0.21^{\mathrm{c} ; \mathrm{B}}$ & $0.05^{\mathrm{c} ; \mathrm{A}}$ & $2.71^{b ; A}$ & \\
\hline RB5 & $5.87^{\mathrm{a} ; \mathrm{A}}$ & $0.72^{c ; A}$ & $0.26^{\mathrm{d} ; \mathrm{A}}$ & $1.71^{\mathrm{b} ; \mathrm{B}}$ & \\
\hline RBBR & 5.87 a; A & $0.43^{b ; B}$ & $0.18^{\text {c; } \mathrm{A}}$ & $0.40^{b ; C}$ & \\
\hline \multicolumn{5}{|c|}{ Radicle damage (\%) } & $1.37 / \leq 0.0001$ \\
\hline $\mathrm{CV}$ & 0.00 d; A & $96.36^{a ;}$ A & $99.15^{\text {a; }} \mathrm{A}$ & $53.82^{b ; C}$ & \\
\hline RB5 & $0.00 \mathrm{~d} ; \mathrm{A}$ & $87.80^{b ; B}$ & $95.64^{\mathrm{a} ; \mathrm{A}}$ & $70.85^{\text {c; B }}$ & \\
\hline RBBR & $0.00^{\mathrm{c} ; \mathrm{A}}$ & $92.70 \mathrm{~b} ; \mathrm{A}$ & $96.88^{a ; A}$ & $93.12^{\mathrm{ab} ; \mathrm{A}}$ & \\
\hline
\end{tabular}

${ }^{\Psi}$ All tests were performed with $2 \mathrm{mg} \mathrm{mL}^{-1}$ at $25^{\circ} \mathrm{C}$, which is a concentration below the water-solubility limit of each of the dyes (50, 550 and $10-50 \mathrm{mg} \mathrm{ml}^{-1}$ for CV, RB5 RBBR, respectively). * Control: seeds treated with water. SE: standard error of the mean. ${ }^{a-d}$ Means in rows with different superscripts indicate significant differences between treatments $(p \leq 0.05)$. A-C Means in columns with different superscripts indicate significant differences between dyes $(p \leq 0.05)$.

Table 5. Phytotoxicity of the dyes on P. sativum seeds before and after $24 \mathrm{~h}$ treatment with T. maxima LE130 and Trametes sp. LA1 cultures.

\begin{tabular}{|c|c|c|c|c|c|}
\hline Dye $^{\Psi}$ & Control * & Untreated Dye & LE130-Treated Dye & LA1-Treated Dye & $\mathrm{SE} / p$-Value \\
\hline \multicolumn{5}{|c|}{ Germination inhibition (\%) } & $3.97 / \leq 0.0001$ \\
\hline $\mathrm{CV}$ & $6.67 \mathrm{~b} ; \mathrm{A}$ & $6.67 \mathrm{~b} ; \mathrm{A}$ & 50.00 a; A & $0.00 \mathrm{~b} ; \mathrm{A}$ & \\
\hline RB5 & $6.67^{\mathrm{a} ; \mathrm{A}}$ & $0.00^{\mathrm{a} ; \mathrm{A}}$ & 0.00 a; B & $0.00^{\mathrm{a} ; \mathrm{A}}$ & \\
\hline RBBR & $6.67^{\mathrm{a} ; \mathrm{A}}$ & 0.00 a; A & $3.33^{\mathrm{a} ; \mathrm{B}}$ & $0.00^{\mathrm{a} ; \mathrm{A}}$ & \\
\hline \multicolumn{5}{|c|}{ Radicle length (cm) } & $0.05 / \leq 0.0001$ \\
\hline $\mathrm{CV}$ & $1.27 \mathrm{a} ; \mathrm{A}$ & $0.75^{\mathrm{b} ; \mathrm{B}}$ & $0.49^{\mathrm{c} ; \mathrm{A}}$ & $0.82^{b ; B}$ & \\
\hline RB5 & $1.27^{\mathrm{a} ; \mathrm{A}}$ & $1.49^{\mathrm{a} ; \mathrm{A}}$ & $0.67 \mathrm{c} ; \mathrm{A}$ & $1.12^{\mathrm{a} b ; \mathrm{A}}$ & \\
\hline RBBR & $1.27^{\mathrm{a} ; \mathrm{A}}$ & $1.32^{\mathrm{a} ; \mathrm{A}}$ & $0.58^{\mathrm{b} ; \mathrm{A}}$ & $1.36^{\mathrm{a} ; \mathrm{A}}$ & \\
\hline \multicolumn{5}{|c|}{ Radicle damage (\%) } & $3.33 / \leq 0.0001$ \\
\hline $\mathrm{CV}$ & $0.00^{\mathrm{c} ; \mathrm{A}}$ & $40.67^{\mathrm{b} ; \mathrm{A}}$ & $61.33^{\mathrm{a} ; \mathrm{A}}$ & $35.33 \mathrm{~b} ; \mathrm{A}$ & \\
\hline RB5 & $0.00^{\mathrm{b} ; \mathrm{A}}$ & $0.00^{b ; B}$ & $47.67^{\mathrm{a} ; \mathrm{A}}$ & $14.67^{b ; B}$ & \\
\hline RBBR & $0.00 \mathrm{~b} ; \mathrm{A}$ & $2.67^{b ; B}$ & $54.67^{\mathrm{a} ; \mathrm{A}}$ & $0.00^{b ; B}$ & \\
\hline
\end{tabular}

${ }^{\Psi}$ All tests were performed with $2 \mathrm{mg} \mathrm{mL}^{-1}$ at $25{ }^{\circ} \mathrm{C}$, concentration below the water-solubility limit of each of the dyes $\left(50,550\right.$ and $10-50 \mathrm{mg} \mathrm{mL}^{-1}$ for CV, RB5 RBBR, respectively). ${ }^{*}$ Control: seeds treated with water. SE: standard error of the mean. ${ }^{\mathrm{a}-\mathrm{b}}$ Means in rows with different superscripts indicate significant differences between treatments $(p \leq 0.05)$. A-B Means in columns with different superscripts indicate significant differences between dyes $(p \leq 0.05)$. 
Damage was registered in R. sativus cotyledons as a result of dye exposition (Figure 3A) and in radicle calyptra of $P$. sativum seeds (Figure 3B). Treatment with Trametes LA1 diminished the damage observed (Figure 3C).

A

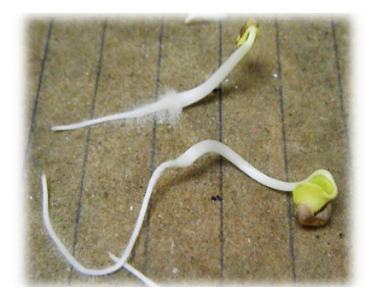

B

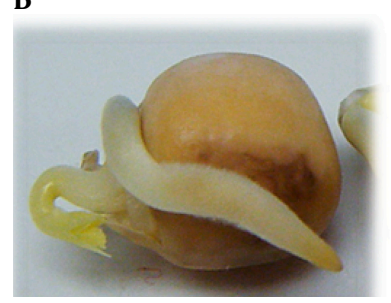

C

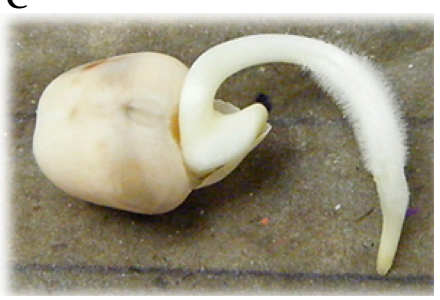

Figure 3. (A) Damage observed in R. sativus seedlings exposed 5 days to RB5 treated T. maxima LE130 cultures; (B) P. sativum seedlings after being exposed 5 days to the LE130-treated dye; (C) P. sativum seedling exposed to CV treated with Trametes sp. LA1 (LA1-treated dye).

In overview, the phytotoxicity of the azoic dye RB5 and the triphenylmethane CV treated with Trametes sp. LA1 decreased by around $15 \%$ and $45 \%$ when tested in $R$. sativus seeds, while the toxicity of $\mathrm{CV}$ and the anthraquinonic dye RBBR diminished by approximately $42 \%$ and $48 \%$ when assayed with P. sativum seeds (Table 6). On the contrary, T. maxima LE130-treated dyes were more toxic than the abiotic controls. RB5 toxicity decreased after treatment with Phanerochaete sordida laccase [46]. The laccase from Trametes pubescens also decreased the toxicity of the azo dye Congo Red [47] (Si et al., 2013). The degradation of azo dyes OII and Acid Orange 6 by laccase from T. versicolor was also accompanied by a decrease of phytotoxicit [10]. The triphenylmethane dye Malachite Green proved to be detoxified by Pleurotus florida [48] and Fomes sclerodermeus [49] laccases. However, the results may vary with the dye assayed; for example, Ramsay and Nguyen (2002) [14] treated various textile dyes with T. versicolor. After decolorization, the toxicity of the solutions containing Amaranth, Tropaeolin O and RB5 was unchanged and Reactive Blue 15, RBBR and Cibacron Brilliant Red 3G-P decreased to non-toxic levels, but Cibacron Brilliant Yellow 3B-A and Congo Red became very toxic.

Table 6. Detoxification determined with R. sativus or P. sativum seeds.

\begin{tabular}{ccccccc}
\hline \multirow{2}{*}{ Seed } & \multicolumn{2}{c}{ RB5 } & \multicolumn{2}{c}{ CV Detoxification (\%) } & \multicolumn{2}{c}{ RBBR } \\
\cline { 2 - 7 } & LE130 & LA1 & LE130 & LA1 & LE130 & LA1 \\
\hline R. sativus & $0^{\mathrm{a}}$ & $15.24^{\mathrm{a}}$ & $0^{\mathrm{a}}$ & $44.39^{\mathrm{a}}$ & $0^{\mathrm{a}}$ & $0^{\mathrm{b}}$ \\
P. sativum & $0^{\mathrm{a}}$ & $0^{\mathrm{b}}$ & $0^{\mathrm{a}}$ & $41.71^{\mathrm{b}}$ & $0^{\mathrm{a}}$ & $48^{\mathrm{a}}$ \\
\hline
\end{tabular}

$\mathrm{a}-\mathrm{b}$ Means in columns with different superscripts indicate significant differences between treatments $(p \leq 0.05)$.

\section{Conclusions}

There is currently growing interest in assessing the potential of new microorganisms for industrial and environmental applications, including wastewater treatment. More than $70 \%$ of freshwater resources in Mexico are affected as a result of pollution from all sources, with $31 \%$ described as contaminated or grossly contaminated [50]. Trametes sp. LA1-a new, isolated strain from Mexicowhen cultivated in a low-cost medium based on bran flakes, produced laccase as the main ligninolytic enzyme detected in its culture fluids and was capable of decolorizing and detoxifying chemically diverse dyes, without the addition of redox mediators. The major drawback of the enzymatic treatment is the inactivation of enzymes in the conditions normally found in textile wastewater and the high cost of enzyme production [51]. Based on these results, it is suggested that Trametes sp. LA1 might be a notable candidate for wastewater biodecolorization. 
Author Contributions: Conceptualization, C.E.H.-L., J.P.G.-R. and G.G.-S.; Data curation, G.M.-Z. and G.G.-S.; Formal analysis, L.N.L., I.L.-S. and G.G.-S.; Investigation, L.N.L., C.E.H.-L., J.P.G.-R. and G.G.-S.; Methodology, C.E.H.-L., J.P.G.-R. and G.G.-S.; Project administration, C.E.H.-L. and G.G.-S.; Resources, C.E.H.-L. and G.G.-S.; Software, G.N.-M., I.L.-S., G.M.-Z. and G.G.-S.; Supervision, C.E.H.-L. and G.G.-S.; Validation, L.N.L., C.E.H.-L., G.N.-M., J.P.G.-R., I.L.-S. and G.G.-S.; Visualization, L.N.L., I.L.-S. and G.G.-S.; Writing-Original draft, L.N.L. and G.G.-S.; Writing-Review \& editing, L.N.L. and G.G.-S.; Funding acquisition: Support Program for Scientific and Technological Research (PAICYT 2019, project CT724-19).

Funding: This research received no external funding.

Acknowledgments: To the Autonomous University of Nuevo León for the support of this research.

Conflicts of Interest: The authors declare no conflict of interests.

\section{References}

1. Hassaan, M.A.; El-Nemr, A. Health and environmental impacts of dyes: Mini Review. AJESE 2017, 1, 64-67. [CrossRef]

2. Rawat, D.; Mishra, V.; Sharma, R.S. Detoxification of azo dyes in the context of environmental processes. Chemosphere 2016, 155, 591-605. [CrossRef] [PubMed]

3. Mani, S.; Bharagava, R.N. Exposure to crystal violet, its toxic, genotoxic and carcinogenic effects on environment and its degradation and detoxification for environmental safety. Rev. Environ. Contam. Toxicol. 2016, 237, 71-104. [CrossRef]

4. Spina, F.; Junghanns, C.; Donelli, I.; Nair, R.; Demarche, P.; Romagnolo, A.; Freddi, G.; Agathos, S.N.; Varese, G.C. Stimulation of laccases from Trametes pubescens: Use in dye decolorization and cotton bleaching. Prep. Biochem. Biotechnol. 2016, 46, 639-647. [CrossRef]

5. Patel, A.M.; Patel, V.M.; Pandya, J.; Trivedi, U.B.; Patel, K.C. Evaluation of catalytic efficiency of Coriolopsis caperata DN laccase to decolorize and detoxify RBBR dye. Water Conserv. Sci. Eng. 2017, 2, 85-98. [CrossRef]

6. Kokol, V.; Doliska, A.; Eichlerova, I.; Baldrian, P.; Nerud, F. Decolorization of textile dyes by whole cultures of Ischnoderma resinosum and by purified laccase and Mn-peroxidase. Enzyme Microb. Technol. 2007, 40, 1673-1677. [CrossRef]

7. Zouari-Mechichi, H.; Mechichi, T.; Dhouib, A.; Sayadi, S.; Martinez, A.T.; Martinez, M.J. Laccase purification and characterization from Trametes trogii isolated in Tunisia: Decolorization of textile dyes by the purified enzyme. Enzyme Microb. Technol. 2006, 39, 141-148. [CrossRef]

8. Zimbardi, A.; Camargo, P.; Carli, S.; Aquino Neto, S.; Meleiro, L.; Rosa, J.; De Andrade, A.; Jorge, J.; Furriel, R. A high redox potential laccase from Pycnoporus sanguineus RP15: Potential application for dye decolorization. Int. J. Mol. Sci. 2016, 17, 672. [CrossRef]

9. Zille, A.; Ramalho, P.; Tzanov, T.; Millward, R.; Aires, V.; Cardoso, M.H.; Ramalho, M.T.; Gubitz, G.M.; Cavaco-Paulo, A. Predicting dye biodegradation from redox potentials. Biotechnol. Prog. 2004, 20, 1588-1592. [CrossRef]

10. Legerská, B.; Chmelová, D.; Ondrejovič, M. Decolourization and detoxification of monoazo dyes by laccase from the white-rot fungus Trametes versicolor. J. Biotechnol. 2018, 285, 84-90. [CrossRef]

11. Zubbair, N.A.; Ajao, A.T.; Adeyemo, E.O.; Adeniyi, D.O. Biotransformation and detoxification of reactive black dye by Ganoderma tsugae. Afr. J. Environ. Sci. Technol. 2018, 12, 158-171. [CrossRef]

12. Mishra, S.; Maiti, A. Applicability of enzymes produced from different biotic species for biodegradation of textile dyes: A review. Clean Technol. Environ. 2019, 2, 763-781. [CrossRef]

13. Nunes, C.S.; Kunamneni, A. Laccases-Properties and Applications. In Enzymes in Human and Animal Nutrition; Elsevier: Chennai, India, 2018; pp. 133-161. [CrossRef]

14. Ramsay, J.A.; Nguyen, T. Decoloration of textile dyes by Trametes versicolor and its effect on dye toxicity. Biotechnol. Lett. 2002, 24, 1756-1760. [CrossRef]

15. Champagne, P.P.; Ramsay, J.A. Dye decolorization and detoxification by laccase immobilized on porous glass beads. Bioresour. Technol. 2010, 101, 2230-2235. [CrossRef]

16. Anastasi, A.; Parato, B.; Spina, F.; Tigini, V.; Prigione, V.; Varese, G.C. Decolourisation and detoxification in the fungal treatment of textile wastewaters from dyeing processes. New Biotechnol. 2011, 29, 38-45. [CrossRef]

17. CONABIO (Comisión Nacional para el Conocimiento y Uso de la Biodiversidad). La Diversidad Biológica de México: Estudio de país. México. 2006. Available online: http://www.conabio.gob.mx/2ep/images/3/37/ capital_natural_2EP.pdf (accessed on 24 September 2019). 
18. Aguirre-Acosta, E.; Ulloa, M.; Aguilar, S.; Cifuentes, J.; Valenzuela, R. Biodiversidad de hongos en México. Rev. Mex. Biodivers. 2014, 85, S76-S81. [CrossRef]

19. Cruz-Ramírez, M.G.; Rivera-Ríos, J.M.; Téllez-Jurado, A.; Gálvez, A.M.; Mercado-Flores, Y.; Arana-Cuenca, A. Screening for thermotolerant ligninolytic fungi with laccase, lipase, and protease activity isolated in Mexico. J. Environ. Manag. 2012, 95, S256-S259. [CrossRef]

20. Gutiérrez-Soto, G.; Medina-González, G.E.; Treviño-Ramírez, J.E.; Hernández-Luna, C.E. Native macrofungi that produce lignin-modifying enzymes, cellulases, and xylanases with potential biotechnological applications. BioResources 2015, 10, 6676-6689. [CrossRef]

21. Krumova, E.; Kostadinova, N.; Staleva, J.; Stoyancheva, G.; Spassova, B.; Abrashev, R.; Angelova, M. Potential of ligninolytic enzymatic complex produced by white-rot fungi from genus Trametes isolated from Bulgarian forest soil. Eng. Life Sci. 2018, 18, 692-701. [CrossRef]

22. Pickard, M.A.; Vandertol, H.; Roman, R.; Vazquez-Duhalt, R. High production of ligninolytic enzymes from white rot fungi in cereal bran liquid medium. Can. J. Microbiol. 1999, 45, 627-631. [CrossRef]

23. Bezalel, L.; Hadar, Y.; Cerniglia, C.E. Enzymatic mechanisms involved in phenanthrene degradation by the white rot fungus Pleurotus ostreatus. Appl. Environ. Microbiol. 1997, 63, 2495-2501. Available online: https://aem.asm.org/content/aem/63/7/2495.full.pdf (accessed on 27 October 2019). [PubMed]

24. Harazono, K.; Nakamura, K. Decolorization of mixtures of different reactive textile dyes by the white-rot basidiomycete Phanerochaete sordida and inhibitory effect of polyvinyl alcohol. Chemosphere 2005, 59, 63-68. [CrossRef] [PubMed]

25. Kumar, V.V.; Kirupha, S.D.; Periyaraman, P.; Sivanesan, S. Screening and induction of laccase activity in fungal species and its application in dye decolorization. Afr. J. Microbiol. Res. 2011, 5, 1261-1267. [CrossRef]

26. Abadulla, E.; Tzanov, T.; Costa, S.; Robra, K.H.; Cavaco-Paulo, A.; Gübitz, G.M. Decolorization and detoxification of textile dyes with a laccase from Trametes hirsuta. Appl. Environ. Microbiol. 2000, 66, 3357-3362. [CrossRef]

27. Wariishi, H.; Valli, K.; Gold, M.H. Manganese (II) oxidation by manganese peroxidase from the basidiomycete Phanerochaete chrysosporium. Kinetic mechanism and role of chelators. J. Biol. Chem. 1992, 267, 23688-23695. Available online: http://www.jbc.org/content/267/33/23688.full.pdf (accessed on 27 October 2019).

28. Tien, M.; Kirk, T.K. Lignin peroxidase of Phanerochaete chrysosporium. Method Enzymol. 1988, 161, $238-249$. [CrossRef]

29. Grafin, D.E. One dimensional gel electrophoresis. Method Enzymol. 1990, 182, 425-444. [CrossRef]

30. Sahu, R.K.; Katiyar, S.; Yadav, A.K.; Kumar, N.; Srivastava, J. Toxicity assessment of industrial effluent by bioassays. Clean 2008, 36, 517-520. [CrossRef]

31. Sobrero, M.C.; Ronco, A. Ensayo de toxicidad aguda con semillas de lechuga Lactuca sativa L. In Ensayos Toxicológicos Para la Evaluación de Sustancias Químicas en Agua y Suelo. La Experiencia en México; Secretaría de Medio Ambiente y Recursos Naturales: Ciudad de México, Mexico, 2008; pp. 55-68. Available online: https://micrositios.inecc.gob.mx/publicaciones/libros/573/cap4.pdf (accessed on 27 October 2019).

32. Ellis, R.H.; Hong, T.D.; Roberts, E.H. Handbook of seed technology for genebanks. Volume I. Principles and Methodology. In Handbooks for Genebanks, No. 2; International Board for Plant Genetic Resources: Rome, Italy, 1985.

33. Alcalde, M.; Butler, T.; Arnold, F.H. Colorimetric assays for biodegradation of polycyclic aromatic hydrocarbons by fungal laccases. J. Biomol. Screen 2002, 7, 547-553. [CrossRef]

34. Archibald, F. A new assay for lignin-type peroxidases employing the dye azure B. Appl. Environ. Microbiol. 1992, 58, 3110-3116. Available online: https://aem.asm.org/content/aem/58/9/3110.full.pdf (accessed on 27 October 2019).

35. Rivela, I.; Rodríguez-Couto, S.; Sanromán, A. Extracellular ligninolytic enzyme production by Phanerochaete chrysosporium in a new solid-state bioreactor. Biotechnol. Lett. 2000, 22, 1443-1447. [CrossRef]

36. Knapp, J.S.; Newby, P.S.; Reece, L.P. Decolorization of dyes by wood-rotting basidiomycete fungi. Enzyme Microb. Technol. 1995, 17, 664-668. [CrossRef]

37. Gianfreda, L.; Xu, F.; Bollag, J. Laccases: A useful group of oxidoreductive enzymes. Bioremdiat. J. 1999, 3, 1-25. [CrossRef]

38. Ahn, M.Y.; Dec, J.; Kim, J.E.; Bollag, J.M. Bioremediation and biodegradation treatment of 2,4-dichlorophenol polluted soil with free and immobilized laccase. J. Environ. Qual. 2002, 31, 1509-1515. [CrossRef] 
39. Baldrian, P. Purification and characterization of laccase from the white rot fungus Daedalea quercina and decolorization of synthetic dyes by the enzyme. Appl. Microbiol. Biotechnol. 2004, 63, 560-563. [CrossRef]

40. Johannes, C.; Majcherczyk, A. Natural mediators in the oxidation of polycyclic aromatic hydrocarbons by laccase mediator systems. Appl. Environ. Microbiol. 2000, 66, 524-528. [CrossRef]

41. Michniewicz, A.; Ledakowicz, S.; Ullrich, R.; Hofrichter, M. Kinetics of the enzymatic decolorization of textile dyes by laccase from Cerrena unicolor. Dyes Pigments 2008, 77, 295-302. [CrossRef]

42. Rodriguez, E.; Pickard, M.A.; Vazquez-Duhalt, R. Industrial dye decolorization by laccases from ligninolytic fungi. Curr. Microbiol. 1999, 38, 27-32. [CrossRef]

43. Aretxaga, A.; Romero, S.; Sarra, M.; Vicent, T. Adsorption step in the biological degradation of a textile dye. Biotechnol. Prog. 2001, 17, 664-668. [CrossRef]

44. Levin, L.; Papinutti, L.; Forchiassin, F. Evaluation of Argentinean white rot fungi for their ability to produce lignin-modifying enzymes and decolorize industrial dyes. Bioresour. Technol. 2004, 94, 169-176. [CrossRef]

45. Pointing, S.B.; Vrijmoed, L.L.P. Decolorization of azo and triphenylmethane dyes by Pycnoporus sanguineus producing laccase as the sole phenoloxidase. World J. Microbiol. Biotechnol. 2000, 16, 317-318. [CrossRef]

46. Permpornsakul, P.; Prasongsuk, S.; Lotrakul, P.; Eveleigh, D.E.; Kobayashi, D.Y.; Imai, T.; Punnapayak, H. Biological treatment of reactive black 5 by resupinate white rot fungus Phanerochaete sordida PBU 0057. Pol. J. Environ. Stud. 2016, 25, 1167-1176. [CrossRef]

47. Si, J.; Peng, F.; Cui, B. Purification, biochemical characterisation and dye decolorization capacity of an alkali-resistant and metal-tolerant laccase from Trametes pubescens. Bioresour. Technol. 2013, 128, 49-57. [CrossRef] [PubMed]

48. Sathishkumar, P.; Palvannan, T.; Murugesan, K.; Kamala-Kannan, S. Detoxification of malachite green by Pleurotus florida laccase produced under solid-state fermentation using agricultural residues. J. Environ. Technol. 2013, 34, 139-147. [CrossRef] [PubMed]

49. Papinutti, V.L.; Forchiassin, F. Modification of malachite green by Fomes sclerodermeus and reduction of toxicity to Phanerochaete chrysosporium. FEMS Microbiol. Lett. 2004, 231, 205-209. [CrossRef]

50. Conagua (2011). Informe Estadísticas del agua en México, Comisión Nacional del Agua (Conagua). Available online: http://www.conagua.gob.mx/CONAGUA07/Publicaciones/Publicaciones/SGP1-11-EAM2011.PDF (accessed on 27 September 2019).

51. Rodríguez-Couto, S. Treatment of textile wastewater by white-rot fungi: still a far away reality? TLIST 2013, 2, 113-119.

(C) 2019 by the authors. Licensee MDPI, Basel, Switzerland. This article is an open access article distributed under the terms and conditions of the Creative Commons Attribution (CC BY) license (http://creativecommons.org/licenses/by/4.0/). 